\title{
A case of complete albinism in the catfish Cambeva guareiensis (Siluriformes: Trichomycteridae)
}

\author{
Valter M. Azevedo-Santos ${ }^{1 *}$, Fernando M. Pelicice ${ }^{2}$, Ivan Sazima ${ }^{3}$, Raoul Henry ${ }^{l}$ \\ ${ }^{1}$ Universidade Estadual Paulista "Júlio de Mesquita Filho”, Departamento de Zoologia, Botucatu, SP, Brasil. \\ ${ }^{2}$ Universidade Federal do Tocantins, Núcleo de Estudos Ambientais, Porto Nacional, TO, Brasil. \\ ${ }^{3}$ Universidade Estadual de Campinas, Museu de Zoologia, Campinas, SP, Brasil. \\ *Corresponding author: Valter M. Azevedo-Santos, e-mail: valter.ecologia@gmail.com
}

AZEVEDO-SAnTOS, V.M., PELICICE, F.M., SAZIMA, I., HENRY, R. A case of complete albinism in the catfish Cambeva guareiensis (Siluriformes: Trichomycteridae). Biota Neotropica 20(4): e20201066. https://doi.org/10.1590/1676-0611-BN-2020-1066

\begin{abstract}
Albinism has been recorded in Neotropical freshwater fishes, mostly for nocturnal or cryptobiotic species. We report herein a case of albinism in the catfish Cambeva guareiensis (Trichomycteridae) from the Guareí River basin, Upper Paraná River basin, southeastern Brazil. The albino fish was caught with seven individuals with typical color pattern of the species. The features of the albino fish in life and shortly after preservation are described and illustrated.

Keywords: Albinism; color anomaly; fish; Guarei River basin; Neotropical region; Paranapanema River basin.

\section{Um caso de albinismo completo no bagrinho Cambeva guareiensis (Siluriformes: Trichomycteridae)}

Resumo: Albinismo tem sido registrado em peixes de água doce Neotropicais, principalmente em espécies noturnas ou criptobióticas. Relatamos aqui um caso de albinismo no bagrinho Cambeva guareiensis (Trichomycteridae) da bacia do Rio Guareí, bacia do Alto Rio Paraná, sudeste do Brasil. O peixe albino foi capturado juntamente com sete indivíduos com padrão de cor típico da espécie. As caracteristicas do peixe albino em vida e logo após a preservação são descritas e ilustradas.

Palavras-chave: Albinismo; anomalia de cor; bacia do Rio Guareí; bacia do Rio Paranapanema; peixe, região Neotropical.
\end{abstract}

\section{Introduction}

Like several other vertebrate groups, fishes may display different types of physical abnormalities (e.g., Bhagat \& Kumar 2014; Catelani et al. 2017), among them those related to color such as different types of albinism (e.g., Nobile et al. 2016). A completely albino individual is characterized by pinkish or yellowish color and pink or red eyes (e.g., Sazima \& Pombal-Jr. 1986; Oliveira \& Foresti 1996; Silva et al. 2013). Currently, a small number of cases of complete albinism is recorded for Neotropical freshwater fishes, mostly in epigeal habitats (e.g., del Barco \& Panattieri 1980; Oliveira \& Foresti 1996; Brito \& Caramaschi 2005; Silva et al. 2013), although albinism is known in hypogeal habitats as well (Carvalho \& de Pinna 1986). To date, reports of complete albinos among trichomycterid catfishes remain restricted to the cave-dwelling Trichomycterus itacarambiensis Trajano \& de Pinna, 1996 (Carvalho \& de Pinna 1986; Trajano 1997).

During a field work (Azevedo-Santos et al. 2020) at the Guareí River basin, an important tributary of the Upper Paranapanema River, Brazil, a complete albino specimen of the catfish Cambeva guareiensis Katz \& Costa 2020 (Trichomycteridae) was caught together with normal individuals. Herein we describe and illustrate the case.

\section{Material and Methods}

Cambeva guareiensis individuals were collected on 20 September 2017 in the Corrente stream $\left(-23.434932^{\circ}-48.388694^{\circ}\right)$, in the Guareí River basin, Upper Paranapanema River, São Paulo State, southeastern Brazil (Azevedo-Santos et al. 2020). The Corrente stream presents clear waters along its course. In the sampled site the substrate is composed mostly of rocks; the riparian vegetation is relatively well preserved, especially if compared to other streams in the Guareí River basin. Specimens of this trichomycterid catfish were collected in a stretch above a waterfall, with rapid waters and rocky substrate. Collection methods (hand net), euthanasia, fixation and preservation of the specimens are fully described in AzevedoSantos et al. (2020).

The eight specimens caught in the same stretch had their standard length (SL, $0.1 \mathrm{~mm}$ ) measured under stereomicroscope and were deposited in the collection of the Departamento de Zoologia e Botânica, UNESP, São José do Rio Preto, SP, Brazil (DZSJRP 23090). Names for the varied forms of albinism followed mostly Henle et al. (2017) for amphibians, as we found no comparable definitions and descriptions for fishes. 


\section{Results}

The complete albino individual of Cambeva guareiensis has 28.3 $\mathrm{mm}$ SL and the normally pigmented individuals measure between 30.1 and $56.0 \mathrm{~mm}$ SL. The body proportions of the albino are similar to those of the normal specimens. In addition, meristics are within the range expected for normal specimens. In life, the albino had pink eyes, a yellowish color dorsally and pink laterally, and the opercle and the region immediately after pectoral fins were red (Figure 1a-b). Due to its small size and the photographic perspective, the eyes are best viewed on the right side of the albino in dorsal view (Figure 1b). Shortly after fixed in formalin, the specimen showed a yellowish color dorsally and laterally. The ventral region was slightly yellow to white. The eyes and the operculum were whitish, the rays of all fins were light yellow (Figure 2a). Pigmented individuals had brown spots dorsally and laterally, with a midline composed of larger spots. The ventral region was yellowish to white (Figure 2b).

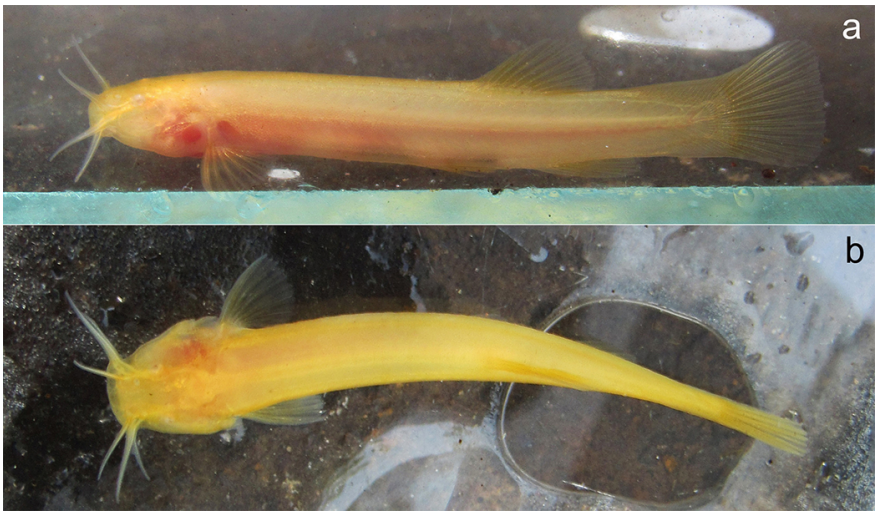

Figure 1. Cambeva guareiensis complete albino in life: (a) left side and (b) dorsal view (DZSJRP 23090).

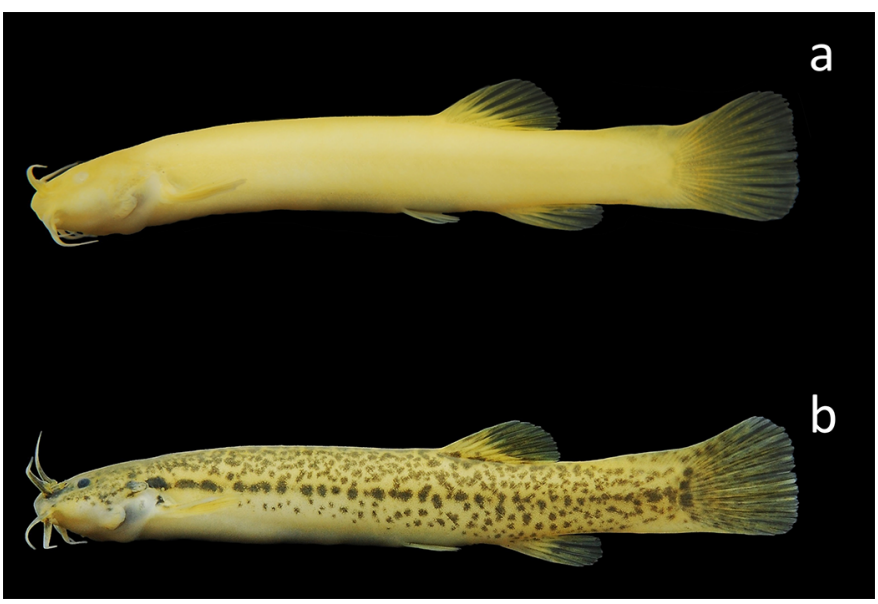

Figure 2. Cambeva guareiensis individuals shortly after preservation: (a) complete albino (28.3 mm SL) and (b) normal color pattern (30.1 mm SL) (DZSJRP 23090).

\section{Discussion}

The lack of pigmentation and pink eyes qualify the atypical Cambeva guareiensis individual as a complete albino (sensu Henle et al. 2017).
The yellowish tinge and red eyes are typical traits of complete albinos (Sazima \& Pombal-Jr. 1986; Oliveira \& Foresti 1996; Silva et al. 2013). Therefore, the color of our specimen should not be confused with xanthism or flavism (sensu Henle et al. 2017), since xanthic individuals have pigmented eyes.

Cambeva guareiensis, a recently described species (Katz \& Costa 2020), seems to be the second complete albino trichomycterid recorded to date. In a population of the cave-dwelling Trichomycterus itacarambiensis studied by Trajano (1997), there are depigmented individuals with red eyes (Carvalho \& de Pinna 1986), which qualify them as complete or true albinos. However, it is difficult to qualify complete albinism in species that lack eyes, a typical trait in troglobiont organisms. This is the case of eyeless fish dwellling in caves and other types of hypogeal waters (Shibatta et al. 2007; Felice et al. 2008).

Complete or true albinos are rarely reported for the Neotropics, and most of them are catfishes (Siluriformes) belonging to several families including Callichthyidae, Doradidae, Heptapteridae, Loricariidae, and Trichomycteridae (del Barco \& Panattieri 1980; Carvalho \& de Pinna 1986; Sazima \& Pombal-Jr. 1986; Burgess 1989; Brito \& Caramaschi 2005; Manoel et al. 2017). There are two records of complete albinos in Gymnotidae (Campos-da-Paz \& Caramaschi 1994; Oliveira \& Foresti 1996) and one in Erythrinidae (Silva et al. 2013). The gymnotid and erythrinid fishes have nocturnal behavior, as is the case of most catfishes, a trait that may favor the survival of albino individuals in a natural environment (Sazima \& Pombal-Jr. 1986). Cambeva guareiensis, like most trichomycterid species (Arratia \& Huaquín 1995; de Pinna \& Wosiacki 2003) is mostly nocturnal and cryptic, which favors its survival face to diurnal, visually hunting predators, as previously suggested for small albino catfishes in general (Sazima \& Pombal-Jr. 1986; Brito \& Caramaschi 2005; Manoel et al. 2017).

\section{Addendum}

We refrained here from labelling our report on Cambeva guareiensis as a first case of albinism within the genus, even if it seems to be the only record of an albino of this species, and the second case of complete albinism within Trichomycteridae (Carvalho \& de Pinna 1986; Trajano 1997). To illustrate our point, an albino described by Sazima \& Pombal Jr (1986) was identified as Rhamdella minuta Lütken, 1874, according to the taxonomic knowledge of this group at the time of publication (H. A. Britski pers. comm.). However, I.S. later recognized the specimen as Imparfinis mirini Haseman, 1911 (Figure 3). Unaware of this situation, Manoel et al. (2017) reported on a first case of albinism in I. mirini, when the supposed $R$. minuta was, indeed, the first record of albinism the former species.

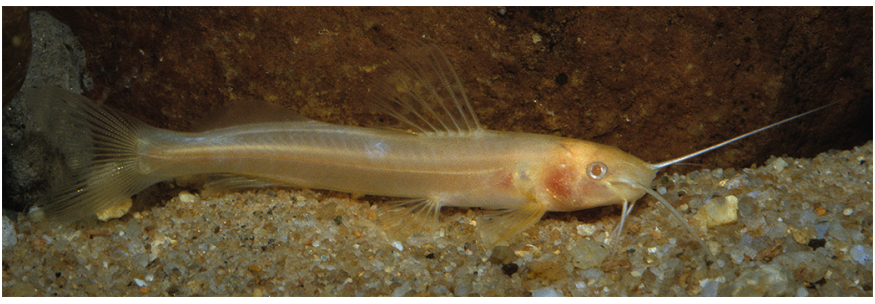

Figure 3. Imparfinis mirini complete albino, identified as Rhamdella minuta in Sazima \& Pombal (1986). Adult specimen 46.4 mm SL (ZUEC 1438). 
We take the opportunity to clear the facts about I. mirini albinos (Sazima \& Pombal Jr. 1986; Manoel et al. 2017), and recommend that the word "first" should be used with care whatever the case or occurrence reported.

\section{Acknowledgements}

We thank Hamilton A. Rodrigues (UNESP), for constant assistance provided; Ricardo R. Benine (UNESP), for help with Figure 2. André B. Nobile (UNESP), Andréa Bialetzki (UEM), Ângelo A. Agostinho (UEM), and Reinaldo J. Castro (UFSCar), for revision of a previous version (in the thesis of the first author) of this manuscript.

\section{Author Contributions}

Valter M. Azevedo-Santos: Collected and identified the specimen and wrote the first draft.

Fernando M. Pelicice: Collaborated with the writing process.

Ivan Sazima: Collaborated with the writing process.

Raoul Henry: Collaborated with the writing process.

\section{Conflicts of interest}

None.

\section{References}

ARRATIA, G. \& HUAQÍN, L. 1995. Morphology of the lateral system and of the skin of diplomystid and certain primitive loricarioid catfishes and systematic and ecological considerations. Bonn. Zool. Monogr. 36: 1-109.

AZEVEDO-SANTOS, V.M., PELICICE, F.M. \& HENRY, R. 2020. Knowing biodiversity: Fishes from the Guareí River basin, a tributary of the Jurumirim reservoir, Paranapanema River, Brazil. Biota Neotrop. 20(3): e20201031. https://doi.org/10.1590/1676-0611-bn-2020-1031

BHAGAT, N. \& KUMAR, R. 2014. Deformities in some fresh water fish of river Tawi Injammu (J\&K). The Bioscan, Int. Quart. J. Life Sci. 9(3): 991-996.

BRITO, M.F.G. \& CARAMASCHI, E.P. 2005. An albino armored catfish Schizolecis guntheri (Siluriformes: Loricariidae) from an Atlantic Forest coastal basin. Neotrop. Ichthyol. 3(1): 123-125. http://dx.doi.org/10.1590/ S1679-62252005000100009

BURGESS, W.E. 1989. An atlas of freshwater and marine catfishes: a preliminary survey of the Siluriformes. New Jersey: TFH Publications, $784 \mathrm{pp}$.

CAMPOS-DA-PAZ, R. \& CARAMASCHI, E.P. 1994. First record of albinism in a gymnotiform fish (Teleostei: Ostariophysi). Ichthyol. Explor. Fres. 5(1): 1-4.

CARVALHO, A.M. \& DE PINNA, M.C.C. 1986. Estudo de uma população hipógea de Trichomycterus (Ostariophysi, Siluroidei, Trichomycteridae) da gruta Olhos d'Água, MG. Espeleo-Tema 15: 53-64.
CATELANI, P.A., BAUER, A.B., DI DARIO, F., PELICICE, F.M. \& PETRY, A.C. 2017. First record of pughead deformity in Cichla kelberi (Teleostei: Cichlidae), an invasive species in an estuarine system in south-eastern Brazil. J. Fish Biol. 90(6): 2496-2503. https://doi.org/10.1111/jfb.13323

DEL BARCO, D. \& PANATTIERI, A. 1980. Un caso de albinismo en armado chancho (Oxydoras kneri, Bleeker 1862) (Pisces - Doradidae). Com. Mus. Prov. Cienc. Natur. Florentino Ameghino 9: 8-19.

FELICE, V., VISCONTI, M.A. \& TRAJANO, E. 2008. Mechanisms of pigmentation loss in subterranean fishes. Neotrop. Ichthyol. 6(4): 657-662.

HENLE, K., DUBOIS, A. \& VERSHININ, V. 2017. Commented glossary, terminology and synonymies of anomalies in natural populations of amphibians. Mertensiella 25: 9-48.

KATZ, A.M. \& COSTA, W.J.E.M. 2020. A new species of the catfish genus Cambeva from the Paranapanema river drainage, southeastern Brazil (Siluriformes: Trichomycteridae). Trop. Zool. 33(1): 2-13.

MANOEL, P.S., ONO, E.R. \& ALVES, M.I.B. 2017. First report of albinism in the South American catfish Imparfinis mirini (Siluriformes: Heptapteridae). Rev. Mex. Biodivers. 88(2): 471-473. https://doi.org/10.1016/j.rmb .2017 .01 .030

NOBILE, A.B., FREITAS-SOUZA, D., LIMA, F.P., ACOSTA, A.A. \& SILVA, R.J. 2016. Partial albinism in Rhinelepis aspera from the Upper Paraná Basin, Brazil, with a review of albinism in South American freshwater fishes. Rev. Mex. Biodivers. 87(2): 531-534. https://doi.org/10.1016/j. rmb.2016.04.005

OLIVEIRA, C. \& FORESTI, F. 1996. Albinism in the banded knifefish, Gymnotus carapo. Trop. Fish. Hobbyist 44(12): 92-96.

DE PINNA, M.C.C. \& WOSIACKI W.B. 2003. Family Trichomycteridae (pencil or parasitic catfishes). In Check list of the freshwater fishes of South and Central America. (L.M. Reis, S. O. Kullander, org.). Porto Alegre: Edipucrs, p. 270-290.

SAZIMA, I. \& POMBAL-JR, J.P. 1986. Um albino de Rhamdella minuta, com notas sobre comportamento (Osteichthyes, Pimelodidae). Rev. Bras. Biol. 46(2): 377-381.

SHIBATTA, O.A., MURIEL-CUNHA, J. \& DE PINNA, M.C.C. 2007. A new subterranean species of Phreatobius Goeldi, 1905 (Siluriformes, Incertae sedis) from the Southwestern Amazon basin. Pap. Avul. Zool. 47(17): 191-201.

SILVA, T.R.M., ARAÚJO, T.A.T. \& BICUDO, A.J.A. 2013. First report of albinism in trahira Hoplias malabaricus from Brazil. Bol. Inst. Pesca 39(4): 457-460.

TRAJANO, E. 1997. Population ecology of Trichomycterus itacarambiensis, a cave catfish from eastern Brazil (Siluriformes, Trichomycteridae). Environ. Biol. Fish. 50: 357-369. https://doi.org/10.1023/A:1007366119261

Received: 17/06/2020

Revised: $06 / 08 / 2020$

Accepted: 17/08/2020

Published online: 25/08/2020 